\title{
EFISIENSI USAHATANI TEBU DI KABUPATEN PURWOREJO
}

\author{
Sugarcane Farming Efficiency in Purworejo Regency
}

Dewi Intan Febianti, Jamhari, Slamet Hartono

\begin{abstract}
Sugar is one of the most crusial comodity that the demand continue to increase along with population growth. Nowdays, Indonesia's sugar production can not be able to meet the demand. Optimal allocation of factors production can deliver optimum production of sugarcane with the appropriate combination of its resources. This study was undertaken to identify the factors affecting sugarcane production in Purworejo, to identify allocative efficiency of sugarcane farming, to identify the revenue and profit of sugarcane farming and to identify the factors affecting revenue of sugarcane's farmers in Purworejo. Data were analyzed using descriptive statistics. The location of the study has been chosen in Purworejo, Middle Java. Data were collected from 60 sugarcane farmers. The result showed that factors affecting sugarcane production in Purworejo were land use, seeds, phonska, pesticide, on farm labour and harvest labour. Allocative efficiency was examined by Ki function, Ki showed $>1$. It means that all significant major inputs were not optimum. The allocative efficiency could be achieved by increasing of existing production inputs. Net revenue was $R$ p. 19.824.598,85 per hectare and the profit per hectare was $R p$. 16.785.428,07. Sugarcane farming $R / C$ ratio in Purworejo was $2,19(R / C>1)$. It showed that is suitable to be extend. The analysis revelaed that factors affecting revenue of sugarcane farming were land use, normalized seeds price, normalized phonska price and normalized labour price.
\end{abstract}

Keywords: Allocative Efficiency, Net Revenue and Profit, Production, Sugarcane.

\section{INTISARI}

Gula merupakan salah satu kebutuhan pokok masyarakat yang meningkat kebutuhannya seiring bertambahnya jumlah penduduk. Saat ini produksi gula dalam negeri belum mampu memenuhi kebutuhan konsumsi. Alokasi penggunaan faktor produksi menentukan produksi yang dihasilkan, semakin optimal penggunaannya maka produksi tebu juga akan meningkat. Penelitian ini bertujuan untuk mengetahui faktor- faktor yang mempengaruhi produksi tebu, mengetahui efisiensi alokatif penggunaan faktor-faktor produksi usahatani tebu, mengetahui pendapatan dan keuntungan dalam usahatani tebu dan mengetahui faktor-faktor yang mempengaruhi pendapatan usahatani tebu. Metode yang digunakan dalam penelitian adalah metode deskriptif. Lokasi penelitian dipilih secara sengaja yaitu di Kabupaten Purworejo, Jawa Tengah dengan responden sebanyak 60 petani. Hasil analisis regresi menunjukan faktor-faktor yang mempengaruhi produksi tebu di Kabupaten Purworejo adalah luas lahan, bibit, jumlah phonska, jumlah pestisida, tenaga kerja garap dan panen. Hasil perhitungan efisiensi alokatif dihitung menggunakan fungsi Ki, nilai Ki menunjukan angka lebih dari 1 yang berarti usahatani tebu di Kabupaten Purworejo belum efisien secara alokatif sehingga perlu di tambah penggunaannya. Pendapatan usahatani tebu per hektar adalah Rp. 19.824.598,85 dan keuntungan per hektar adalah Rp. 16.785.428,07. R/C rasio usahatani tebu di Kabupaten Purworejo adalah 2,19 menunjukan usahatani layak untuk terus diusahakan. Berdasarkan analisis regresi faktor-faktor yang mempengaruhi besarnya pendapatan usahatani tebu di Kabupaten Purworejo adalah luas lahan, harga bibit yang dinormalkan, harga phonska yang dinormalkan, harga tenaga kerja garap dan tenaga kerja panen yang dinormalkan.

Kata kunci: Efisiensi Alokatif, Pendapatan dan Keuntungan, Produksi, Tebu.

\section{PENDAHULUAN}

Tebu (Sacharum officinarum) merupakan tanaman yang ditanam untuk bahan baku pembuatan gula. Tanaman ini termasuk jenis rumput-rumputan. Tebu termasuk dalam tanaman semusim atau Annual Crops dimana umur tanaman sejak ditanam sampai bisa dipanen mencapai kurang lebih satu tahun. Tebu diolah di Pabrik Gula (PG) untuk selanjutnya diolah untuk menghasilkan Gula Kristal Putih (GKP) dan tetes sebagai produk utama.
Gula merupakan salah satu kebutuhan pokok masyarakat dan akan terus meningkat kebutuhannya seiring dengan pertambahan penduduk dan perkembangan industri makanan dan minuman. Pada tahun 2014 diperkirakan konsumsi gula nasional mencapai 5,7 juta ton/tahun, sehingga dicanangkan gerakan itensifikasi dalam rangka swasembada gula (Romli, 2012). Pesatnya perkembangan kebutuhan gula sementara peningkatan produksi relatif belum seimbang menjadikan Indonesia sebagai importir 
gula baik untuk gula kristal mentah (raw sugar) maupun gula industri (refined sugar).

Alokasi penggunaan faktor produksi bisa menentukan produksi yang dihasilkan. Semakin optimal penggunaan faktor produksinya maka produksi tebu juga akan semakin meningkat. Oleh karena itu dengan menghitung efisiensi alokatif penggunaan faktor produksi maka diharapkan kita dapat memahami bahwa di Kabupaten Purworejo, alokasi faktor produksinya sudah efisien atau belum. Peran gula tidak hanya penting untuk memenuhi kebutuhan masyarakat lokal purworejo namun juga seluruh DIY dan Indonesia maka produksi tebu harus didukung oleh pemerintah agar lebih kompetitif.

\section{TINJAUAN PUSTAKA}

\section{Teori Produksi}

Menurut Debertin(1986), produksi merupakan proses dimana barang dan jasa yang disebut input diubah menjadi barang dan jasa yang disebut sebagai output. Dalam proses produksi terdapat kombinasi dan koordinasi material-material dan kekuatankekuatan input berupa faktor produksi, sumberdaya, atau jasa-jasa produksi dalam pembuatan suatu barang atau jasa (output dan produk). Dengan kata lain suatu kegiatan atau proses mengubah masukan atau input (transformasi) menjadi suatu keluaran atau output disebut proses produksi. Hasil dari proses produksi atau output dalam bidang pertanian atau lainnya dapat bervariasi antara lain disebabkan karena perbedaan kualitas.

Menurut Soedarsono (1998), fungsi produksi adalah hubungan teknis yang menghubungkan antara faktor produksi (input) dan produksi (output). Disebut faktor produksi karena bersifat mutlak, supaya produksi dapat dijalankan untuk menghasilkan produk. Suatu fungsi dikatakan efisien secara teknis ketika penggunaan kauntitas bahan mentah, tenaga kerja, dan barang-barang modal lain adalah minimal. Secara matematika, bentuk persamaan fungsi produksi adalah sebagai berikut:

$$
Q=f(K, L, M)
$$

Dimana $\mathrm{Q}$ adalah output barang-barang tertentu selama satu periode, $\mathrm{K}$ adalah input modal yang digunakan selama satu periode tersebut, $\mathrm{L}$ adalah input tenaga kerja dan $\mathrm{M}$ adalah input bahan mentah yang digunakan. Dari persamaan (2.1) dapat dijelaskan bahwa jumlah output tergantung dari kombinasi penggunaan modal, tenaga kerja, dan bahan mentah yang digunakan. Semakin tepat kombinasi input, semakin besar kemungkinan output dapat diproduksi secara maksimal.

\section{Fungsi Produksi Cobb-Douglas}

Menurut Soekartawi (2003), fungsi produksi Cobb-Douglas adalah suatu fungsi peersamaan yang melibatkan dua atau lebih variabel. Variabel dependen (Y) atau variabel yang dijelaskan, sedangkan variabel lain disebut variabel independen $(\mathrm{X})$ atau variabel yang menjelaskan. Secara matematis fungsi CobbDouglas dapat dituliskan sebagai berikut :

$$
\begin{aligned}
& Y=a X_{1}^{b 1} X_{2}^{b 2} \ldots X_{i}^{b i} \ldots X_{n}^{b n} e^{u} \\
& =a X_{I}^{b i} e^{u}
\end{aligned}
$$

Bila fungsi Cobb-Douglas tersebut dinyatakan oleh hubungan Y dan X, maka:

$$
Y=f(X 1, X 2, \ldots X i, \ldots, X n)
$$

\section{Keterangan:}

$\mathrm{Y}$ : Variabel yang dijelaskan $\mathrm{X}$ : Variabel yang menjelaskan $\mathrm{a}, \mathrm{b}:$ Besaran yang akan diduga

$\mathrm{u}$ : Kesalahan (disturbance term) e : Logaritma natural, $\mathrm{e}=2,718$

Untuk memudahkan pendugaan terhadap persamaan tersebut maka persamaan terlebih dahulu diubah menjadi bentuk linier berganda dengan cara melogaritmakan persamaan tersebut.

$\mathrm{Y}=\mathrm{f}(\mathrm{X} 1, \mathrm{X} 2) \operatorname{dan} Y=a X_{1}^{b 1} X_{2}^{b 2} e^{u}$

Logaritma dari persamaan diatas, adalah:

$\log \mathrm{Y}=\log \mathrm{a}+\mathrm{b} 1 \log \mathrm{X} 1+\mathrm{b} 2 \log \mathrm{X} 2+\mathrm{v} \mathrm{Y}^{*}=\mathrm{a}^{*}$ $+\mathrm{b} 1 \mathrm{X} 1 *+\mathrm{b} 2 \mathrm{X} 2 *+\mathrm{v}^{*}$

\section{Keterangan: $\mathrm{Y}^{*} \quad: \log \mathrm{Y}$ \\ $\mathrm{X}^{*}: \log \mathrm{X}$ \\ $\mathrm{v}^{*}: \log \mathrm{v}$ \\ $\mathrm{a}^{*} \quad: \log \mathrm{a}$}

Pada persamaan tersebut terlihat bahwa nilai b1 dan b2 adalah tetap walaupun variabel yang terlibat telah dilogaritmakan. Hal ini dapat dimengerti karena b1 dan b2 pada fungsi CobbDouglas adalah sekaligus menunjukan elastisitas $\mathrm{X}$ terhadap $\mathrm{Y}$. 


\section{Teori Efisiensi Penggunaan Faktor Produksi}

Efisiensi dalam produksi merupakan ukuran perbandingan antara output dan input. Efisiensi merupakan tindakan memaksimalkan hasil dengan menggunakan modal (tenaga kerja, material dan alat) yang minimal (Daft, 2007; Griffin, 2004). Farrel dalam Indah Susantum (2000) membedakan efisiensi menjadi tiga yaitu efisiensi teknis, efisiensi harga (alokatif), dan efisiensi ekonomis. Efisiensi teknik mengenai hubungan antara input dan output. Efisiensi alokatif tercapai jika penambahan tersebut mampu memaksimalkan keuntungan yaitu menyamakan produk marjinal setiap faktor produksi dengan harganya. Sedangkan efisiensi ekonomi dapat dicapai jika kedua efisiensi yaitu efisiensi teknis dan efisiensi harga dapat tercapai.

\section{Efisiensi Alokatif}

Efisiensi alokatif (harga) berhubungan dengan keberhasilan petani mencapai keuntungan maksimum pada jangka pendek, yaitu efisiensi yang dicapai dengan mengkondisionalkan nilai produk marjinal sama dengan harga input (NPMx $=\mathrm{Px}$ atau indeks efisiensi harga $=\mathrm{ki}=1$ ).

Untuk menghitung indeks efisiensi dari alokasi setiap faktor produksi (ki) digunakan rumus:

$$
\mathrm{Ki}=\frac{\text { biy.py }}{x i \cdot p x i}
$$

\section{Keterangan :}

bi : Elastisitas produksi faktor ke-i

y : rata-rata produksi (output)

py : rata-rata harga output

xi : rata-rata penggunaan faktor produksi ke -i pxi : rata-rata harga faktor produksi ke-i

Jika nilai $\mathrm{ki}=1$, artinya penggunaan input sudah efisien secara alokatif, sedangkan jika nilai $\mathrm{ki}<1$, artinya penggunaan input tidak efisien secara alokatif dan apabila nilai ki $>1$, artinya penggunaan input belum efisien secara alokatif.

\section{Pendapatan dan Keuntungan}

Pendapatan merupakan selisih antara seluruh permintaan dan seluruh pengeluaran (biaya produksi yang betul-betul dikeluarkan) dari berbagai cabang usaha tani. Pendapatan yang dihitung adalah pendapatan atas biaya tunai yaitu selisih antara penerimaan tunai dengan biaya yang dikeluarkan. Secara matematis dapat ditulis sebagai berikut:

$$
\mathrm{NR}=\mathrm{Py} \cdot \mathrm{Y}-(\mathrm{Px} \cdot \mathrm{X}+\mathrm{TFC})_{\text {eksplisit }}
$$

Keterangan :

NR : Net Revenue/Pendapatan (Rp)

TR : Total Revenue/Total Penerimaan (Rp)

$\mathrm{TC}_{\text {eksplisit }}$ :Total Costeksplisit /Total Biaya (Rp)

TVC : Total Variabel Cost/Total Biaya variabel (Rp)

TFC : Total Fixed Cost/Total Biaya Tetap (Rp)

Py : Harga Output

Y : Jumlah Output

Px : Harga Input

$\mathrm{X}$ : Jumlah Input

Keuntungan adalah selisih dari total penerimaan (total revenue) dengan total biaya (total cost) dari hasil usaha yang dikerjakan. Keuntungan secara matematis dapat ditulis sebagai berikut :

$\Pi=$ Py.Y $-(\text { Px. X + TFC })_{\text {Eksplisit }+ \text { Implisit }}$

Keterangan :

$\Pi \quad$ : Profit/Keuntungan (Rp)

TR : Total Revenue/Total Penerimaan (Rp)

$\mathrm{TC}_{\text {Eksplisit + Implisit }}$ :Total Cost/Total Biaya (Rp)

TVC : Total Variabel Cost/Total Biaya Variabel (Rp)

TFC : Total Fixed Cost/Total Biaya Tetap (Rp)

Py : Harga Output

Y : Jumlah Output

Px : Harga Input

$\mathrm{X}$ : Jumlah Input

Untuk melihat keuntungan relatif suatu usaha terhadap biaya dapat digunakan dengan pendekatan $\mathrm{R} / \mathrm{C}$ ratio. $\mathrm{R} / \mathrm{C}$ ratio merupakan perbandingan antara total penerimaan dengan total biaya, atau secara matematis dapat ditulis:

$$
\frac{\mathrm{R}}{\mathrm{C}} \text { ratio }=\frac{\mathrm{TR}}{\mathrm{TC}}
$$

Jika $\mathrm{R} / \mathrm{C}$ ratio $<1$ maka usaha tersebut dikatakan tidak layak dan jika $\mathrm{R} / \mathrm{C}=1$ maka usaha tersebut tidak mendapatkan keuntungan juga tidak rugi.

Untuk mengidentifikasi faktor-faktor yang mempengaruhi pendapatan usahatani dapat 
dianalisis dengan fungsi keuntungan. Fungsi keuntungan Cobb-Douglas yang digunakan dalam penelitian ini adalah fungsi keuntungan yang berasal dari fungsi Cobb- Douglas dengan teknik Unit Output Price (OUP) yang merupakan fungsi yang melibatkan harga produksi dan harga faktor produksi yang dinormalkan dalam bentuk double natural logarithm (Soekartawi, 2003). Dengan menggunakan fungsi Cobb-Douglas, maka fungsi keuntungan yang dinormalkan dalam bentuk double natural logarithm ditulis sebagai berikut :

$$
\operatorname{Ln} \pi^{*}=\ln A^{*+} \Sigma \alpha \mathrm{i} * \ln v \mathrm{i} *+\sum \beta \mathrm{i} * \ln Z \mathrm{i}
$$

\section{Keterangan :}

$\sigma \quad:$ standar deviasi

E : rata-rata hasil (mean)

A : intersep

$\pi *$ : keuntungan yang dinormalkan

$\mathrm{a} *_{\mathrm{i}}$ : koefisien harga produksi variabel ke-i $\beta *_{\mathrm{i}}$ : koefisien faktor produksi tetap

$\mathrm{v}^{*}$ : harga faktor produksi variabel ke-i yang dinormalkan

$\mathrm{Zi}$ : Kuantitas faktor produksi tetap

\section{METODE PENELITIAN}

Metode dasar yang digunakan dalam penelitian ini adalah metode deskriptif, yaitu dengan memusatkan penelitian pada suatu kelompok manusia, subjek, suatu kondisi dan peristiwa yang terjadi serta memusatkan diri pada pemecahan masalah-masalah aktual yang ada pada masa sekarang (Nazir, 2009). Penelitian ini dilakukan di Kabupaten Purworejo Jawa Tengah. Lokasi penelitian dipilih secara sengaja (purposive) dari tiga kecamatan yaitu Kecamatan Purwodadi, Ngombol dan Bayan. Dipilihnya lokasi Kabupaten Purworejo ini karena pada kabupaten tersebut termasuk dalam wilayah produksi tebu PG Madukismo.

\section{Analisis Faktor-Faktor yang Mempengaruhi Produksi Tebu}

Menganalisis faktor-faktor yang mempengaruhi produksi usahatani tebu digunakan Metode Regresi Linier Berganda, dirumuskan sebagai berikut :

$\mathrm{Ln} Y=\ln \mathrm{b} 0+\mathrm{b} 1 \ln \mathrm{X} 1+\mathrm{b} 2 \ln \mathrm{X} 2+\mathrm{b} 3 \ln \mathrm{X} 3+$ $\ldots+\mathrm{b} 7 \ln \mathrm{X} 7+\mathrm{b} 8 \ln \mathrm{X} 8+\mathrm{e}$
Keterangan :

Y : Produksi Tebu (kw)

b0 : Intersep

b1- b6: Koefisien masing-masing variabel

$\mathrm{X1}$ : Luas lahan (ha)

$\mathrm{X} 2$ : Bibit (kw)

X3 : Pupuk Phonzka (kw)

X4 : Pupuk ZA (kw)

X5 : Pupuk Petroganik (kw)

$\mathrm{X} 6$ : Pestisida (liter)

$\mathrm{X} 7$ : Tenaga kerja garap (HKO)

$\mathrm{X} 8$ : Tenaga kerja panen (HKO)

Sebelum melakukan analisis terhadap model, agar mendapat model yang baik maka sebelumnya dilakukan uji asumsi klasik. Uji asumsi klasik yang sering digunakan untuk jenis dara cross section antara lain uji multikolinearitas, heterosdekastisitas, dan autokorelasi (Wijaya, 2009).

\section{Analisis Efisiensi Alokatif Faktor Produksi}

Untuk menghitung indeks efisiensi dari alokasi seiap faktor produksi (ki) digunakan rumus:

$$
\mathrm{Ki}=\frac{\text { bi.y.py }}{\mathrm{xi} \cdot \mathrm{pxi}}
$$

Keterangan :

bi : Elastisitas produksi faktor ke-i y :rata-rata produksi (output)

py : rata-rata harga output

xi : rata-rata penggunaan faktor produksi ke -i pxi : rata-rata harga faktor produksi ke-i

Hipotesisnya adalah :

Jika nilai $\mathrm{ki}=1$, artinya penggunaan input sudah efisien secara alokatif

Jika nilai $\mathrm{ki}<1$, artinya penggunaan input tidak efisien secara alokatif

Jika nilai $\mathrm{ki}>1$, artinya penggunaan input belum efisien secara alokatif

\section{Analisis Pendapatan dan Keuntungan}

Untuk mengetahui besarnya pendapatan yang diperoleh petani dari hasil usahatani tebu secara matematis dapat dituliskan sebagai berikut :

$$
\mathrm{NR}=\mathrm{TR}-\mathrm{TC}_{\text {eksplisit }}
$$

Keterangan :

NR : Net Revenue/Pendapatan (Rp)

TR : Total Revenue/Total Penerimaan (Rp) 
$\mathrm{TC}_{\text {eksplisit }}: \sum$ (Biaya bibit (Rp) + Biaya pupuk (Rp) + Biaya pestisida $(\mathrm{Rp})+$ Biaya tenaga kerja garap dan biaya kerja panen $(\mathrm{Rp})+$ Biaya sewa tanah $(\mathrm{Rp})+$ Bunga pinjaman $(\mathrm{Rp}))$

TVC : $\sum$ (Biaya bibit $(\mathrm{Rp})+$ Biaya pupuk $(\mathrm{Rp})$ + Biaya pestisida $(\mathrm{Rp})+$ Biaya tenaga kerja garap dan biaya kerja panen $(\mathrm{Rp})$

TFC : $\sum$ (Biaya sewa tanah $(\mathrm{Rp})+$ Bunga pinjaman (Rp))

Py : $\sum$ (Harga gula $(\mathrm{Rp} / \mathrm{ku})+$ Harga tetes $(\mathrm{Rp} /$ $\mathrm{ku})$ )

$\mathrm{Y} \quad: \sum$ (Bagi hasil hablur $(\mathrm{ku})+$ Bagi hasil tetes $(\mathrm{ku}))$

Px : $\sum$ (Harga bibit $(\mathrm{Rp} / \mathrm{ku})+$ Harga pupuk $(\mathrm{Rp} /$ $\mathrm{ku})+$ Harga pestisida (Rp/liter) + Harga tenaga kerja garap dan harga tenaga kerja panen (Rp/HKO))

$\mathrm{X} \quad: \sum$ (Jumlah bibit (ku) + jumlah pupuk $(\mathrm{ku})+$ jumlah pestisida (liter) + Jumlah tenaga kerja garap dan tenaga kerja panen (HKO)).

Keuntungan usahatani secara matematis dapat dituliskan sebagai berikut :

$$
\Pi=\mathrm{TR}-\mathrm{TC}_{\text {Eksplisit }+ \text { Implisit }}
$$

\section{Keterangan:}

$\Pi$ : Profit/Keuntungan (Rp)

TR : Total Revenue/Total Penerimaan (Rp)

$\mathrm{TC}_{\text {Eksplisit }+ \text { Implisit }}: \sum$ (TCEksplisit + (Biaya tenaga kerja dalam keluarga $(\mathrm{Rp} / \mathrm{HKO})+$ Biaya penyusutan alat-alat pertanian (Rp) + Biaya bunga modal sendiri + Biaya sewa lahan sendiri (Rp)) )

Py : $\sum$ (Harga gula $(\mathrm{Rp} / \mathrm{ku})+$ Harga tetes $(\mathrm{Rp} /$ $\mathrm{ku})$ )

Y : $\sum$ (Bagi hasil hablur (ku) + Bagi hasil tetes (ku) ).

$\mathrm{R} / \mathrm{C}$ ratio merupakan perbandingan antara total penerimaan dengan total biaya, atau secara matematis dapat ditulis :

$$
\frac{\mathrm{R}}{\mathrm{C}} \text { ratio }=\frac{\mathrm{TR}}{\mathrm{TC}}
$$

Jika $\mathrm{R} / \mathrm{C}$ ratio $<1$ maka usaha tersebut dikatakan tidak layak dan jika $\mathrm{R} / \mathrm{C}=1$ maka usaha tersebut tidak mendapatkan keuntungan juga tidak rugi.

\section{Analisis Faktor-Faktor yang Mempengaruhi Pendapatan Usahatani Tebu}

Untuk menjawab tujuan ke empat, menganalisis faktor-faktor yang mempengaruhi pendapatan usahatani tebu digunakan metode regresi linier berganda, dirumuskan sebagai berikut:

$\mathrm{Ln} P d p t=\ln \mathrm{b} 0+\mathrm{b} 1 \ln \mathrm{X} 1+\mathrm{b} 2 \ln \mathrm{X} 2+\mathrm{b} 3 \ln \mathrm{X} 3$

$$
+\ldots+\mathrm{b} 8 \ln \mathrm{X} 8+\mathrm{e}
$$

Keterangan :

Pdpt : Pendapatan usaha yang dinormalkan (Rp)

b0 : Intersep

b1- b10 : Koefisien masing-masing variabel

$\mathrm{X} 1$ : Luas lahan (ha)

$\mathrm{X} 2$ : Harga bibit yang dinormalkan (Rp)

X3 : Harga Phonska yang dinormalkan (Rp)

$\mathrm{X} 4$ : Harga ZA yang dinormalkan (Rp)

X5 : Harga Petroganik yang dinormalkan (Rp)

$\mathrm{X} 6$ : Harga pestisida yang dinormalkan $(\mathrm{Rp})$

X7 : Harga tenaga kerja garap yang dinormalkan (Rp)

X8 : Harga tenaga kerja panen yang dinormalkan (Rp)

Berdasarkan fungsi diatas, maksud dari harga yang dinormalkan ialah dimana variabel independen dibagi dengan harga produksi. Harga produksi disini ialah harga produksi gula dan harga produksi tetes $(\mathrm{Rp})$.

\section{HASIL DAN PEMBAHASAN}

Penelitian ini dilakukan dengan metode analisis data regresi berganda. Analisis dilakukan dengan software SPSS 17.0 untuk menganalisis faktor-faktor yang mempengaruhi produksi dan faktor-faktor yang mempengaruhi pendapatan. Selain menggunakan SPSS, juga menggunakan microsoft excel untuk menghitung produksi, analisis efisiensi alokatif, pendapatan dan keuntungan. Dari hasil analisis yang dilakukan pada akhirnya akan diambil kesimpulan.

\section{Faktor-Faktor yang Mempengaruhi Produksi Tebu}

Dari Tabel 6.6 diketahui bahwa nilai Adjusted $R 2$ yaitu sebesar 0,897 , hal ini menunjukan bahwa 89,70 persen variabel dependen (produksi) dapat 
Tabel 1. Hasil Uji Regresi Faktor-Faktor yang Mempengaruhi Produksi Tebu di Kabupaten Purworejo

\begin{tabular}{llcc}
\hline \multicolumn{1}{c}{ Variabel } & $\begin{array}{c}\text { Koefisien } \\
\text { regresi }\end{array}$ & t hitung & Sig. \\
\hline Konstanta & $4,447^{* * *}$ & 16,314 & 0,000 \\
Luas lahan & $0,341^{* * *}$ & 3,105 & 0,003 \\
Bibit & $0,338^{* * *}$ & 4,771 & 0,000 \\
Phonska & $0,133^{*}$ & 1,829 & 0,071 \\
ZA & $0,026^{\mathrm{ns}}$ & 0,408 & 0,648 \\
Petroganik & $-0,016^{\mathrm{ns}}$ & $-0,513$ & 0,609 \\
Pestisida & $0,097^{* *}$ & 2,583 & 0,011 \\
Tenaga kerja garap & $0,082^{*}$ & 1,737 & 0,086 \\
Tenaga kerja panen & $0,091^{* *}$ & 2,114 & 0,037 \\
Adjusted R & & & 0,897 \\
\hline F hitung & & & 109,064 \\
\hline F table & & & 2,188 \\
\hline
\end{tabular}

Sumber : Analisis Data Primer, 2014

Keterangan:

$* * *=$ signifikansi pada tingkat kepercayaan $99 \%(\alpha=$ $0,01)$

$* *=$ signifikansi pada tingkat kepercayaan $95 \%(\alpha=$ 0,05 )

* = signifikansi pada tingkat kepercayaan $90 \%(\alpha=$ $0,1)$

Ns $=$ tidak signifikan

dijelaskan oleh variabel independen didalam model (luas lahan, jumlah bibit, jumlah pupuk phonska, jumlah pupuk ZA, jumlah pupuk petroganik, jumlah pestisida, jumlah tenaga kerja garap, jumlah tenaga kerja panen) sedangkan sisanya sebesar 10,3 persen dijelaskan oleh variabel lain diluar model. Berdasarkan hasil analisis bahwa nilai $F$ hitung sebesar 109,064 dan $F$ tabel sebesar 2,188 . Sedangkan ditingkat kepercayaan 95 persen dan apabila dilihat dari nilai $\mathrm{F}$ hitung dan $\mathrm{F}$ tabel $(109,064>2,188)$ maka Ho ditolak sehingga dapat disimpulkan bahwa variabel independen pada model ini model secara bersama-sama berpengaruh secara signifikan terhadap variabel dependen yaitu jumlah produksi.

Luas lahan memiliki nilai signifikansi sebesar 0,003 lebih kecil dari 0,01 yang berarti memiliki tingkat signifikansi 99 persen dan koefisien regresi menunjukan angka 0,341 . Hal ini menunjukan bahwa luas lahan memiliki pengaruh positif terhadap produki tebu. Setiap penambahan luas lahan sebesar 1 persen akan meningkatkan produksi tebu sebesar 0,341 persen. Jumlah bibit berpengaruh secara nyata terhadap produksi tebu dengan hasil analisis menunjukan nilai signifikansi sebesar 0,000 lebih kecil dari 0,01 dengan koefisien regresi sebesar 0,338 . Hal ini menunjukan bahwa jumlah bibit memiliki pengaruh positif terhadap produki tebu. Nilai koefisien regresi menunjukan nilai positif, hal ini berarti setiap penambahan jumlah bibit 1 persen maka akan diikuti penambahan produksi sebesar 0,338 persen.

Jumlah pupuk phonska berpengaruh secara nyata terhadap produksi tebu dengan nilai signifikansi sebesar 0,071 lebih kecil dari 0,1 dengan koefisien regresi sebesar 0,133 . Hal ini menunjukan bahwa jumlah phonska memiliki pengaruh positif terhadap produki tebu. Koefisen regresi menunjukan nilai positif, hal ini menunjukan bahwa setiap penambahan 1 persen phonska akan meningkatkan produksi tebu sebesar 0,133 persen. Nilai signifikansi menunjukan angka sebesar 0,011 lebih kecil dari 0,05 dengan koefisien regresi sebesar 0,97 . Hal ini menunjukan bahwa jumlah pestisida memiliki pengaruh positif terhadap produki tebu. Koefisen regresi menunjukan nilai positif, hal ini menunjukan bahwa setiap penambahan 1 persen pestisida akan meningkatkan produksi tebu sebesar 0,97 persen.

TKG berpengaruh secara nyata terhadap produksi tebu dengan hasil analisis menunjukan nilai signifikansi sebesar 0,086 lebih kecil dari 0,1 dengan koefisien regresi sebesar 0,082. Hal ini menunjukan bahwa tenaga kerja garap memiliki pengaruh positif terhadap produki tebu. Jumlah TKP berpengaruh secara nyata terhadap produksi tebu dengan nilai signifikansi sebesar 0,037 lebih kecil dari 0,05 dengan koefisien regresi sebesar 0,91 . Hal ini menunjukan bahwa tenaga kerja panen memiliki pengaruh positif terhadap produki tebu. Koefisen regresi menunjukan nilai positif, hal ini menunjukan bahwa setiap penambahan 1 persen TKP akan meningkatkan produksi tebu sebesar 0,91 persen.

\section{Efisiensi Alokatif Peggunaan Faktor- faktor Produksi pada Usahatani Tebu}

Hasil analisis efisiensi alokatif di atas menunjukan bahwa semua penggunaan input produksi yakni luas lahan, bibit, phonska, pestisida, tenaga kerja garap dan tenaga kerja panen belum efisien. Hal ini terlihat pada nilai Ki (efisiensi alokatif) menunjukan angka lebih dari 1. Hal ini berarti input produksi perlu ditambah penggunaannya. Untuk medapatkan alokasi penggunaan sarana produksi 
yang efisien maka diperlukan nilai Ki sebesar satu dengan cara membalik rumus efisiensi alokatif yaitu di ibaratkan $\mathrm{Ki}=1$ sehingga bisa dihitung nilai xi (rata-rata penggunaan faktor produksi ke-i). Setelah dilakukan perhitungan, didapat hasil sebagai seperti pada Tabel 3.

Tingkat penggunaan luas lahan sebesar 3,12 Hektar per usahatani belum efisien, setelah dilakukan perhitungan dengan diibaratkan nilai $\mathrm{Ki}$ sama dengan satu, maka di temukan secara alokatif penggunaan luas lahan yang efisien adalah sebesar 6,92 Hektar per usahatani. Sedangkan untuk alokasi penggunaan bibit secara efisien adalah sebesar 118,90 Kuintal per Hektar. Nilai ini lebih besar dibanding alokasi penggunaan bibit yang belum efisien. Berdasarkan Pusat Penelitian dan Pengembangan Perkebunan (2010), rekomendasi bibit per hektar adalah 80-100 kuintal per hektar. Untuk alokasi penggunaan pupuk phonska secara efisien adalah 9,76 Kuintal per Hektar sedangkan menurut rekomendasi penggunaan pupuk Phonska adalah sebesar 6 kuintal per hektar. Nilai ini tidak berbeda jauh dengan perhitungan xi yang efisien, perlu diketahui setiap tanah pada setiap lahan mempunyai kandungan unsur hara yang ber bedabeda sehingga kebutuhan tanah akan usur hara tertentu tak terkecuali phonska menjadi berbedabeda pula.

Penggunaan pestisida 8,09 liter perusahatani $(3,12 \mathrm{Ha})$ dirasa belum efisien sehingga apabila dilakukan penghitungan efisiensi alokatif dengan nilai $\mathrm{Ki}=1$, didapat hasil 10,24 liter per Hektar. Alokasi penggunaan tenaga kerja garap dan tenaga kerja panen sedikit meningkat

Tabel 2. Efisiensi Alokatif Penggunaan Sarana Produksi Usahatani Tebu

\begin{tabular}{lcccc}
\hline \multicolumn{1}{c}{ Input } & Harga & NPM & Ki & Keterangan \\
\hline Luas lahan & $5.703 .333,33$ & $12.546 .920,30$ & 2,36 & Belum Efisien \\
Bibit & 47.120 & $281.876,45$ & 6,48 & Belum Efisien \\
Phonska & 230.000 & $1.441 .385,36$ & 6,26 & Belum Efisien \\
Pestisida & 56.600 & $1.340 .748,99$ & 43,21 & Belum Efisien \\
TK Garap & $44.816,67$ & $94.149,75$ & 2,32 & Belum Efisien \\
TK Panen & $7.139,16$ & $102.715,07$ & 15,39 & Belum Efisien \\
\hline
\end{tabular}

Sumber : Analisis Data Primer, 2014

Tabel 3. Efisiensi Alokatif Penggunaan Sarana Produksi

\begin{tabular}{lcccc}
\hline \multicolumn{1}{c}{ Input } & Harga & $\mathrm{Ki}$ & Xi (Efisien) & Xi (Penggunaan Petani) \\
\hline Luas lahan & $5.73 .333,33$ & & & 3,12 \\
(Per Usahatani,Ha) & & 1 & 6,92 & \\
Biit (Ku/Ha) & 47.120 & 1 & 118,90 & 28,86 \\
Phonska (Ku/Ha) & 230.000 & 1 & 9,76 & 2,79 \\
Pestisida (liter/Ha) & 56.600 & 1 & 10,24 & 2,59 \\
TK Garap (HKO/Ha) & $44.816,67$ & 1 & 279,53 & 77,50 \\
TK Panen (HKO/Ha) & $7.139,16$ & 1 & 277,07 & 77,97 \\
\hline
\end{tabular}

Sumber: Analisis Data Primer, 2014

Tabel 4. Alokasi Biaya pada Usahatani Tebu di Kabupaten Purworejo

\begin{tabular}{llcc}
\hline & Biaya & Per Usahatani & Per Hektar \\
\hline Eksplisit & Bibit & $8.722 .666,67$ & $2.792 .295,79$ \\
& Pupuk & $7.845 .250,83$ & $2.511 .417,86$ \\
& Pestisida & $556.449,58$ & $178.130,37$ \\
& Tenaga Kerja & $30.009 .015,30$ & $9.606 .471,31$ \\
& Sewa Tanah & 1.720 .000 .00 & $550.605,56$ \\
& Bunga Pinjaman & 1.845 .400 .00 & $590.748,55$ \\
Implisit & Biaya TKDK & $2.551 .583,33$ & $816.811,61$ \\
& Biaya penyusutan & $368.034,16$ & $117.814,91$ \\
& Bunga modal sendiri & $2.164 .361,14$ & $692.854,23$ \\
& Biaya sewa lahan sendiri & 4.494 .227 & 1.438 .690 \\
& Total Biaya & $60.276 .987,02$ & 19.295 .840
\end{tabular}

Sumber : Analisis Data Primer, 2014 
setelah dilakukan perhitungan efisiensi alokatif dengan mengibaratkan nilai $\mathrm{Ki}=1$. Berturut turut penggunaan alokasi tenaga kerja garap dan panen adalah 279,53 HKO per Hektar dan 277,07 HKO per Hektar. Nilai tersebut dirasa tidak begitu terlampau jauh dengan penggunaan tenaga kerja sebelumnya, berarti penggunaan tenaga kerja sebelumnya sudah mendekati nilai efisiensi alokatif.

\section{Pendapatan dan Keuntungan Usahatani Tebu}

Dalam penelitian ini akan dianalisis pendapatan dan keuntungan yang didapat oleh petani tebu di Kabupaten Purworejo dalam kegiatan usahataninya. Di atas telah dipaparkan mengenai biaya implisit dan eksplisit petani tebu, di bawah ini akan disajikan Tabel pendapatan petani tebu di Kabupaten Purworejo.

Tabel 5. Pendapatan Petani Tebu di Kabupaten Purworejo

\begin{tabular}{lll}
\hline Uraian & Per Usahatani & Per Hektar \\
\hline Penerimaan & $114.776 .773,27$ & $36.747 .122,49$ \\
Biaya Eksplisit & $52.863 .143,52$ & $16.922 .523,67$ \\
Pendapatan & $61.913 .629,75$ & $19.824 .598,82$ \\
\hline
\end{tabular}

Sumber : Analisis Data Primer, 2014

Berdasarkan Tabel 5 diketahui bahwa penerimaan per hektar sebesar Rp 36.747.122,49 dan pendapatan yang didapat per hektar adalah 19.824.598,82. Selain menghitung pendapatan, dihitung pula profit atau keuntungan petani tebu di Kabupaten Purworejo. Hasil perhitungan dapat dilihat pada tabel 6 .

Tabel 6. Keuntungan Usahatani Tebu di Kabupaten Purworejo

\begin{tabular}{lcc}
\hline Uraian & Per Usahatani & Per Hektar \\
\hline Penerimaan & $114.776 .773,27$ & $36.747 .122,49$ \\
Biaya eksplisit & $52.863 .143,52$ & $16.922 .523,67$ \\
Biaya implisit & $9.578 .205,63$ & $3.066 .170,75$ \\
Profit & $52.335 .424,12$ & 16.758 .428 .07 \\
R/C Ratio & 2,19 & 2,19 \\
\hline
\end{tabular}

Sumber : Analisis Data Primer, 2014

Berdasarkan tabel 6, keuntungan per herktar yang didapat petani tebu dalam kegiatan usahataninya ialah sebesar Rp 16.758.428.07. Layak atau tidaknya suatu usaha dapat dilihat dari nilai $\mathrm{R} / \mathrm{C}$ ratio. Apabila nilai $\mathrm{R} / \mathrm{C}$ ratio $>1$ suatu usaha dikatakan layak, hal ini menunjukan semakin tinggi nilai $\mathrm{R} / \mathrm{C}$ maka tingkat keuntungan suatu usaha semakin tinggi. Jika $\mathrm{R} / \mathrm{C}$ ratio $<1$ maka usaha tersebut dikatakan tidak layak

\section{Faktor-faktor yang Mempengaruhi Pendapatan Usahatani Tebu}

Untuk menganalisis faktor yang mempengaruhi pendapatan digunakan fungsi pendapatan yaitu fungsi keuntungan UOP CobbDouglas (UOP Cobb-Douglas Profit Function). Fungsi keuntungan UOP Cobb- Douglas merupakan fungsi keuntungan yang diturunkan dari fungsi prodduksi tipe Cobb- dan jika $\mathrm{R} / \mathrm{C}=1$ maka usaha tersebut tidak mendapatkan keuntungan juga tidak rugi. Sedangkan untuk nilai $\mathrm{R} / \mathrm{C}$ ratio usahatani tebu di Kabupaten Puroworejo adalah sebesar 2,19 per hektar, sedangkan per usahatani adalah sebesar 2,19 pula. Angka tersebut masing-masing lebih besar dari 1 sehingga dapat disimpulkan bahwa usahatani tebu di Kabupaten Purworejo layak untuk diusahakan.

Douglas dimana diduga faktor-faktor yang mempengaruhi keuntungan adalah tingkat hargaharga input variabel dan jumlah input tetap yang digunakan. Karena dalam model ini menggunakan

Tabel 7. Hasil Uji Regresi Faktor-Faktor yang Mempengaruhi Pendapatan Tebu di Kabupaten Purworejo

\begin{tabular}{lccc}
\hline \multicolumn{1}{c}{ Variabel } & $\begin{array}{c}\text { Koefisien } \\
\text { regresi }\end{array}$ & t hitung & Sig. \\
\hline Konstanta & $7,531^{* * *}$ & 5,622 & 0,000 \\
Luas lahan & $1,045^{* * *}$ & 27,368 & 0,000 \\
Harga Bibit & $-0,485^{*}$ & $-1,713$ & 0,093 \\
Harga Phonska & $-1,413^{*}$ & $-1,785$ & 0,080 \\
Harga ZA & $1,413^{\mathrm{ns}}$ & 2,095 & 0,410 \\
Harga Petroganik & $-0,009^{\mathrm{ns}}$ & $-0,223$ & 0,824 \\
Harga Pestisida & $-0,020^{\mathrm{ns}}$ & $-0,019$ & 0,564 \\
Harga TK garap & $-0,510^{* * *}$ & $-2,885$ & 0,006 \\
Harga TK panen & $-0,790^{* *}$ & $-2,451$ & 0,018 \\
\hline Adjusted R & & & 0,937 \\
\hline F hitung & & & 111,120 \\
\hline F table & & & 2,188 \\
\hline
\end{tabular}

Sumber : Analisis Data Primer, 2014

Keterangan:

$* * *=$ signifikansi pada tingkat kepercayaan $99 \%(\alpha=$ $0,01)$

$* *=$ signifikansi pada tingkat kepercayaan $95 \%(\alpha=$ $0,05)$

* $\quad=$ signifikansi pada tingkat kepercayaan $90 \%(\alpha=$ $0,1) \mathrm{Ns}=$ tidak signifikan 
fungsi keuntungan UOP tipe Cobb-Douglas, maka dalam perhitungan nilai keuntungan dan hargaharga input variabel dibagi dengan harga output.

Dari Tabel 7 diketahui bahwa nilai Adjusted R2 yaitu sebesar 0,937 hal ini menunjukan bahwa 93,7 persen variabel dependen ( pendapatan ) dapat dijelaskan oleh variabel independer didalam model ( luas lahan, harga bibit yang dinormalkan, harga pupuk phonska yang dinormalkan, harga pupuk ZA yang dinormalkan, harga pupuk petroganik yang dinormalkan, harga pestisida yang dinormalkan, harga tenaga kerja garap yang dinormalkan, harga tenaga kerja panen yang dinormalkan) sedangkan sisanya sebesar 6,3 persen dijelaskan oleh variabel lain diluar model.

Uji F dilakukan untuk mengetahui apakah model variabel independen secara bersama-sama berpengaruh secara signifikan terhadap variabel dependen. Berdasarkan hasil analisis bahwa nilai $\mathrm{F}$ hitung sebesar 111,120 dan F tabel sebesar 2,188 . Sedangkan ditingkat kepercayaan 95 persen dan apabila dilihat dari nilai $\mathrm{F}$ hitung dan $\mathrm{F}$ tabel $(111,120>2,188)$ maka Ho ditolak sehingga dapat disimpulkan bahwa variabel independen pada model ini model ( luas lahan, harga bibit yang dinormalkan, harga pupuk phonska yang dinormalkan, harga pupuk ZA yang dinormalkan, harga pupuk petroganik yang dinormalkan, harga pestisida yang dinormalkan, harga tenaga kerja garap yang dinormalkan, harga tenaga kerja panen yang dinormalkan ) secara bersama-sama berpengaruh secara signifikan terhadap variabel dependen yaitu pendapatan.

Luas lahan memiliki nilai signifikansi sebesar 0,000 lebih kecil dari 0,01 yang berarti memiliki tingkat signifikansi 99 persen dan koefisien regresi menunjukan angka 1,045. Hal ini menunjukan bahwa luas lahan memiliki pengaruh positif terhadap pendapatan. Setiap penambahan luas lahan sebesar 1 persen akan menaikan pendapatan sebesar 1,045 persen. Harga bibit yang dinormalkan berpengaruh positif terhadap pendapatan usahatani tebu dengan hasil analisis menunjukan nilai signifikansi sebesar 0,093 lebih kecil dari 0,1 dengan koefisien regresi sebesar -0,485. Nilai koefisien regresi menunjukan nilai negatif, hal ini berarti setiap peningkatan harga bibit 1 persen maka akan diikuti penurunan pendapatan sebesar 0,485 persen. harga phonska yang yang dinormalkan berpengaruh secara nyata terhadap pendapatan, hal ini terlihat dari nilai signifikansi sebesar 0,080 lebih kecil dari 0,1 . Sedangkan nilai koefisien regresinya adalah sebesar -1,389. Nilai koefisien regresi menunjukan angka negatif hal ini mempunyai arti bahwa setiap penambahan satu persen harga phonska, akan menurunkan pendapatan sebesar 1,389 persen.

Harga tenaga kerja garap berpengaruh positif terhadap pendapatan usahatani tebu dengan nilai signifikansi sebesar 0,006 lebih kecil dari 0,01 dengan koefisien regresi sebesar $-0,510$. Koefisen regresi menunjukan nilai negatif, hal ini menunjukan bahwa setiap peningkatan harga 1 persen tenaga kerja garap akan menurunkan pendapatan usahatani tebu sebesar 0,510 persen. Harga tenaga kerja panen berpengaruh positif terhadap pendapatan usahatani tebu dengan nilai signifikansi sebesar 0,018 lebih kecil dari 0,05 dengan koefisien regresi sebesar $-0,790$. Koefisen regresi menunjukan nilai negatif, hal ini menunjukan bahwa setiap penambahan 1 persen harga tenaga kerja panen akan menurunkan pendapatan sebesar 0,790 persen.

\section{KESIMPULAN}

1. Faktor-faktor yang mempengaruhi produksi tebu di Kabupaten Purworejo adalah luas lahan, jumlah bibit, jumlah pupuk phonska, jumlah pestisida, jumlah tenaga kerja garap, dan jumlah tenaga kerja panen.

2. Hasil analisis efisiensi alokatif menunjukan bahwa semua penggunaan input produksi yakni luas lahan, bibit, phonska, pestisida, tenaga kerja garap, dan tenaga kerja panen belum efisien sehingga perlu ditambah alokasi penggunaannya. Hal ini terlihat pada nilai $\mathrm{Ki}$ (efisiensi alokatif) menunjukan angka lebih dari 1.

3. Penggunaan input produksi yang efisien secara alokatif adalah lahan sebesar 6,92 Hektar Per Usahatani, penggunaan bibit sebesar 118,90 kuintal/hektar, pupuk phonska sebesar 9,76 kuintal/hektar, penggunaan pestisida sebesar 10,24 liter/hektar, alokasi TKG sebesar 279,53 HKO/hektar dan alokasi TKP sebesar 277,07 HKO/hektar.

3. Pendapatan per hektar yang didapat petani tebu di Kabupaten Purworejo adalah Rp $19.824 .598,82$

4. Keuntungan per herktar yang didapat petani tebu di Kabupaten Purworejo ialah sebesar Rp 16.758.428.07 dan nilai $\mathrm{R} / \mathrm{C}$ ratio usahatani 
tebu di Kabupaten Puroworejo adalah sebesar 2,19 per hektar, angka tersebut lebih besar dari 1 sehingga dapat disimpulkan bahwa usahatani tebu di Kabupaten Purworejo layak untuk diusahakan.

5. Faktor-faktor yang mempengaruhi pendapatan usahatani tebu di Kabupaten Purv'orejo adalah luas lahan, harga bibit yang dinormalkan, harga Phonska yang dinormalkan, harga tenaga kerja garap yang dinormalkan dan harga tenaga kerja panen yang dinormalkan.

\section{DAFTAR PUSTAKA}

Daft, L.D. 2007. Manajemen. Jilid 1, Edisi 6: Terjemahan. Salemba Empat. Jakarta.

Dibertin, D.L. 1986. Agricultural Production Economics. Macmillan Publishing Co. New York.
Nazir, Mohammad. 2009. Metode Penelitian. Ghalia Indonesia. Bogor.

Romli, Moch. 2012. Sistem Pertanian Terpadu Tebu-Ternak Mendukung Swasembada Gula dan Daging. Kementrian Riset dan Teknologi, Jakarta.

Soedarsono. 1998. Pengantar Ekonomi Mikro. LP3ES. Jakarta.

Soekartawi. 2003. Teori Ekonomi Produksi (Dengan Pokok Bahasan Analisis Fungsi Cobb-Douglas). Raja Grafindo. Jakarta.

Susantum, Indah. 2000. Fungsi keuntungan CobbDouglas dalam pendugaan efisiensi ekonomi relatif. Jurnal Ekonomi Pembangunan. Vol:5 No:2 hal : 149-162. 